\title{
OBESITAS DAN PENGARUHNYA TERHADAP KARDIOVASKULAR
}

\author{
Mauliza $^{1}$ \\ ${ }^{1}$ Program Studi Kedokteran, Fakultas Kedokteran, Universitas Malikussaleh
}

Corresponding Author : mauliza@unimal.ac.id

\begin{abstract}
Abstrak
Obesitas didefinisikan sebagai suatu kelainan atau penyakit yang ditandai dengan penimbunan jaringan lemak tubuh secara berlebihan. Peningkatan prevalensi obesitas pada anak menjadi fokus perhatian terhadap keterlibatan struktur dan fungsi kardiovaskular. Obesitas pada masa anak merupakan prediktor obesitas dan meningkatkan risiko kardiovaskular pada masa dewasa. Obesitas pada anak dan remaja dapat meningkatkan risiko berbagai masalah kardiovaskular. Peningkatan Indeks Massa Tubuh (IMT) merupakan faktor risiko terjadinya peningkatan tekanan darah, sindroma metabolik, abnormalitas ketebalan dinding pembuluh darah, disfungsi endotel dan hipertrofi ventrikel kiri. Konsumsi makanan tinggi kalori yang besar, pengeluaran energi yang kurang dan atau kombinasi keduanya menyebabkan keseimbangan energi positif dengan peningkatan rata-rata berat badan pada populasi dan progresivitas jumlah kasus obesitas pada anak dan remaja.
\end{abstract}

Kata Kunci :obesitas;anak ;kardiovaskular

\section{OBESITY AND EFFECT ON CARDIOVASCULAR}

\begin{abstract}
Obesity is an abnormality or disease characterized by excessive accumulation of body fat tissue. Increased prevalence of obesity in children is the focus of attention on cardiovascular structure and function involvement. Obesity in childhood is a predictor of obesity and increases cardiovascular risk in adulthood. Obesity in children and adolescents can increase the risk of various cardiovascular problems. Increased Body Mass Index (BMI) is a risk factor for increased blood pressure, metabolic syndrome, vascular wall thickness abnormalities, endothelial dysfunction and left ventricular hypertrophy. Consumption of high-calorie foods, less energy expenditure and or a combination of both causes a positive energy balance with an increase in the average body weight in the population and increases the number of cases of obesity in children and adolescents.
\end{abstract}

Keywords: obesity;children;cardiovascular 


\section{PENDAHULUAN}

Obesitas mulai menjadi masalah kesehatan di seluruh dunia, bahkan World Health Organization (WHO) menyatakan bahwa obesitas merupakan suatu epidemi global sehingga menjadi masalah kesehatan yang harus segera ditangani. ${ }^{1}$ Prevalensi terjadinya overweight dan obesitas pada anak mengalami peningkatan di seluruh dunia, tidak saja di negara-negara maju tetapi juga di negara yang sedang berkembang. ${ }^{2}$ Sekitar 155 juta anak dengan overweight di seluruh dunia dengan 30 sampai 45 juta anak mengalami obesitas. ${ }^{3}$

Perubahan gaya hidup di kota-kota besar termasuk di Indonesia yang menjurus ke westernisasi dan sedentary berakibat pada perubahan pola makan atau konsumsi masyarakat yang merujuk pada pola makan tinggi kalori, tinggi lemak dan kolesterol terutama terhadap penawaran makanan siap saji (fast food) yang berdampak meningkatkan risiko obesitas. ${ }^{1}$

Peningkatan prevalensi obesitas pada anak menjadi fokus perhatian terhadap keterlibatan struktur dan fungsi kardiovaskular. ${ }^{4}$ Obesitas pada masa anak merupakan prediktor obesitas dan meningkatkan risiko kardiovaskular pada masa dewasa. ${ }^{5}$ Berbagai bukti menunjukkan komplikasi obesitas yang terjadi saat dewasa dimulai sejak masa anak-anak. ${ }^{6}$

\section{DEFINISI DAN KRITERIA OBESITAS}

Obesitas didefinisikan sebagai suatu kelainan atau penyakit yang ditandai dengan penimbunan jaringan lemak tubuh secara berlebihan. ${ }^{1}$ Secara klinis obesitas dengan mudah dapat dikenali karena mempunyai tanda dan gejala yang khas seperti wajah yang membulat, pipi yang tembem, dagu rangkap, leher relatif pendek, dada yang membusung dengan payudara yang membesar mengandung jaringan lemak, perut membuncit disertai dinding perut yang berlipatlipat. Pada anak lelaki dijumpai penis tampak kecil karena tersembunyi dalam jaringan suprapubik (burried penis). ${ }^{7}$

Berdasarkan antopometris, umumnya obesitas pada anak ditentukan berdasarkan tiga metode pengukuran sebagai berikut: ${ }^{7}$

1. Mengukur berat badan dan hasilnya dibandingkan dengan berat badan ideal sesuai tinggi badan $(\mathrm{BB} / \mathrm{TB})$. Obesitas pada anak didefinisikan sebagai berat badan menurut tinggi badan di atas persentil ke-90 atau 120\% dibandingkan berat badan ideal.

2. The World Health Organization (WHO), The National Institutes of Health (NIH) dan The Expert Committee on Clinical Guidelines for Overweight in Adolescent Preventive Services telah merekomendasikan Indeks Massa Tubuh (IMT) sebagai baku pengukuran obesitas pada anak dan remaja di atas usia 2 tahun. Nilai batas IMT untuk kelebihan berat badan pada anak dan remaja adalah persentil ke-85 dan ke-95. Klasifikasi IMT terhadap umur yaitu lebih besar atau sama dengan persentil ke-85 adalah overweight dan lebih besar atau sama dengan persentil ke-95 adalah obesitas. 
3. Pengukuran langsung lemak subkutan dengan mengukur tebal lipatan kulit (TLK). Terdapat empat macam cara pengukuran TLK yang ideal untuk mendapatkan proporsi lemak tubuh, yaitu TLK biseps, triseps, subskapular dan suprailiaka. Indikator obesitas bila TLK triseps di atas persentil ke-85.

\section{ETIOLOGI DAN PATOFISIOLOGI OBESITAS}

Obesitas merupakan suatu kondisi yang dapat disebabkan oleh berbagai faktor seperti genetik, metabolisme, perilaku, budaya dan lingkungan. Konsumsi makanan tinggi kalori, pengeluaran energi yang kurang atau kombinasi keduanya menyebabkan keseimbangan energi positif yang ditandai dengan peningkatan rata-rata berat badan pada populasi serta progresivitas jumlah kasus obesitas pada anak dan remaja. ${ }^{8}$

Leptin merupakan hormon yang bekerja memberikan umpan balik negatif dalam mengatur keseimbangan energi. Sirkulasi leptin melewati darah dan otak berinteraksi dengan reseptor pada neuron mempengaruhi keseimbangan energi dan memberikan efek untuk mengurangi adiposit dengan mengurangi nafsu makan dan peningkatan termogenesis. Perubahan adiposit pada tubuh menyebabkan perubahan kadar leptin pada sirkulasi sehingga otak akan memberikan respon dengan pengaturan asupan dan pengeluaran energi serta mempertahankan lemak tubuh. ${ }^{9}$

Gambar 1 menunjukkan penyesuaian kompensasi dari asupan dan pengeluaran energi terhadap respon perubahan lemak tubuh.

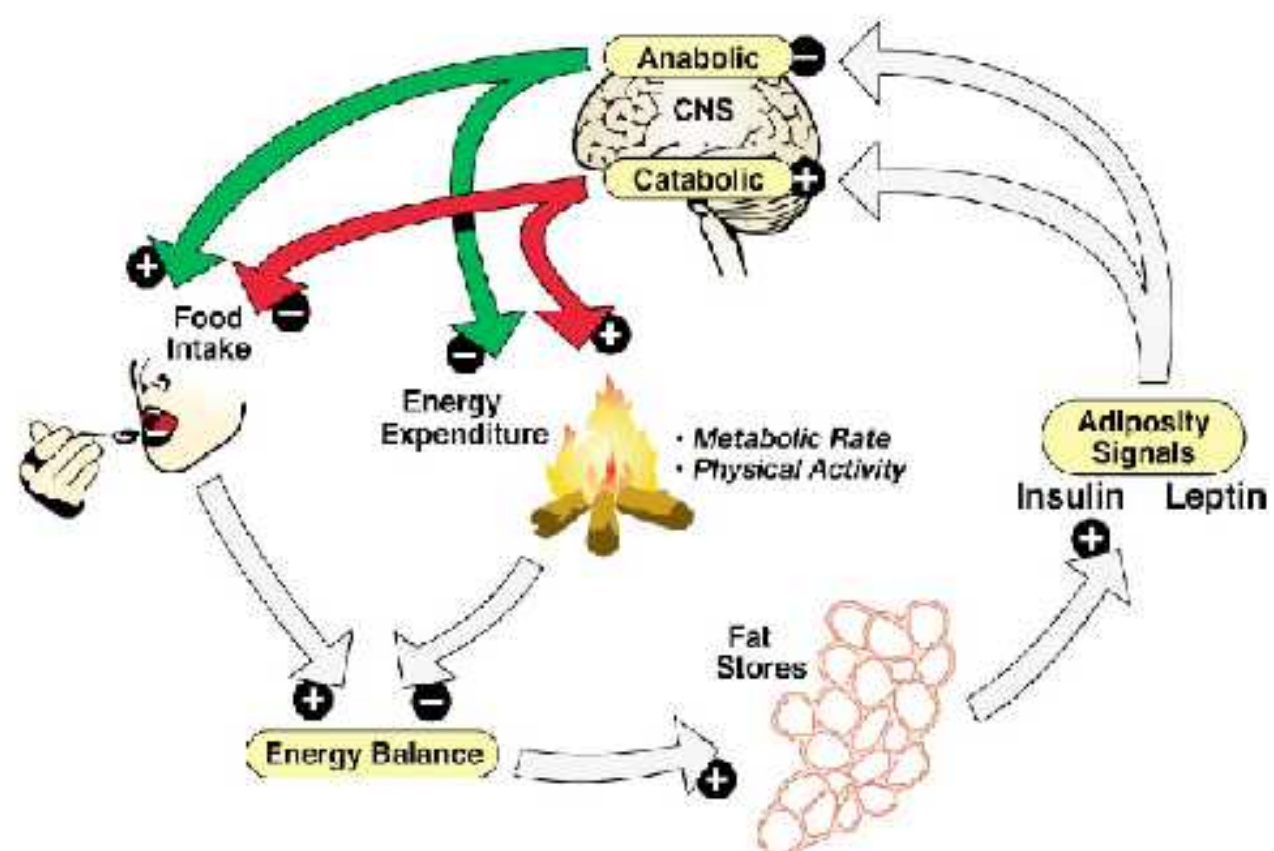

Gambar 1. Kompensasi perubahan asupan makanan terhadap lemak tubuh ${ }^{9}$ 


\section{PENGARUH OBESITAS PADA ANAK}

Obesitas pada anak dan remaja dapat meningkatkan risiko kardiovaskular. Peningkatan Indeks Massa Tubuh (IMT) merupakan faktor risiko terjadinya peningkatan tekanan darah, sindroma metabolik, abnormalitas ketebalan dinding pembuluh darah, disfungsi endotel dan hipertrofi ventrikel kiri. ${ }^{3}$ Overweight dan obesitas berhubungan dengan perubahan struktur jantung seperti peningkatan diameter atrium, dimensi dan massa ventrikel kiri serta peningkatan tekanan darah dibandingkan anak dengan berat badan normal. ${ }^{4}$

Tabel 1. Berbagai risiko kardiovaskular pada anak dan remaja obes ${ }^{3}$

\begin{tabular}{ll}
\hline Faktor kardiovaskular/metabolik & Risiko/akibat \\
\hline Tekanan darah & Peningkatan tekanan darah \\
Arteri sistemik & Disfungsi endotel \\
& Peningkatan kekakuan arteri karotis \\
& Peningkatan ketebalan intima-media pada arteri karotis \\
Struktur/geometri ventrikel kiri & Peningkatan massa ventrikel kiri/hipertrofi ventrikel kiri \\
& Peningkatan diameter ventrikel kiri \\
Sindroma metabolik & Pengelompokkan faktor risiko kardiovaskular (obesitas, \\
& peningkatan tekanan darah, resistensi insulin, dislipidemia) \\
\hline
\end{tabular}

Obesitas merupakan faktor penyebab terjadinya perubahan preklinis pada jantung: ${ }^{10}$

1. Volume overload menyebabkan peningkatan curah jantung dan hipertensi.

2. Sistem aktivitas simpatetik renin-angiotensin-aldosterone menyebabkan hipertensi.

3. Hiperinsulinemia/resistensi insulin, meningkatkan advance glycation end-products (AGE) dan insulin-like growth factor-1 (IGF-1) serta sebagai perantara pengambilan asam lemak yang dapat menyebabkan kerusakan sel lipotoxic.

4. Jaringan lemak viseral mempengaruhi stress oksidatif dan berhubungan dengan penurunan kadar leptin atau resistensi leptin dan penurunan kadar adiponectin.

5. Perubahan selular dipengaruhi oleh faktor neurohumoral, metabolik, stress oksidatif dan adipokin yang menyebabkan fibrosis dan apoptosis ekstraselular. (Gambar 2). 


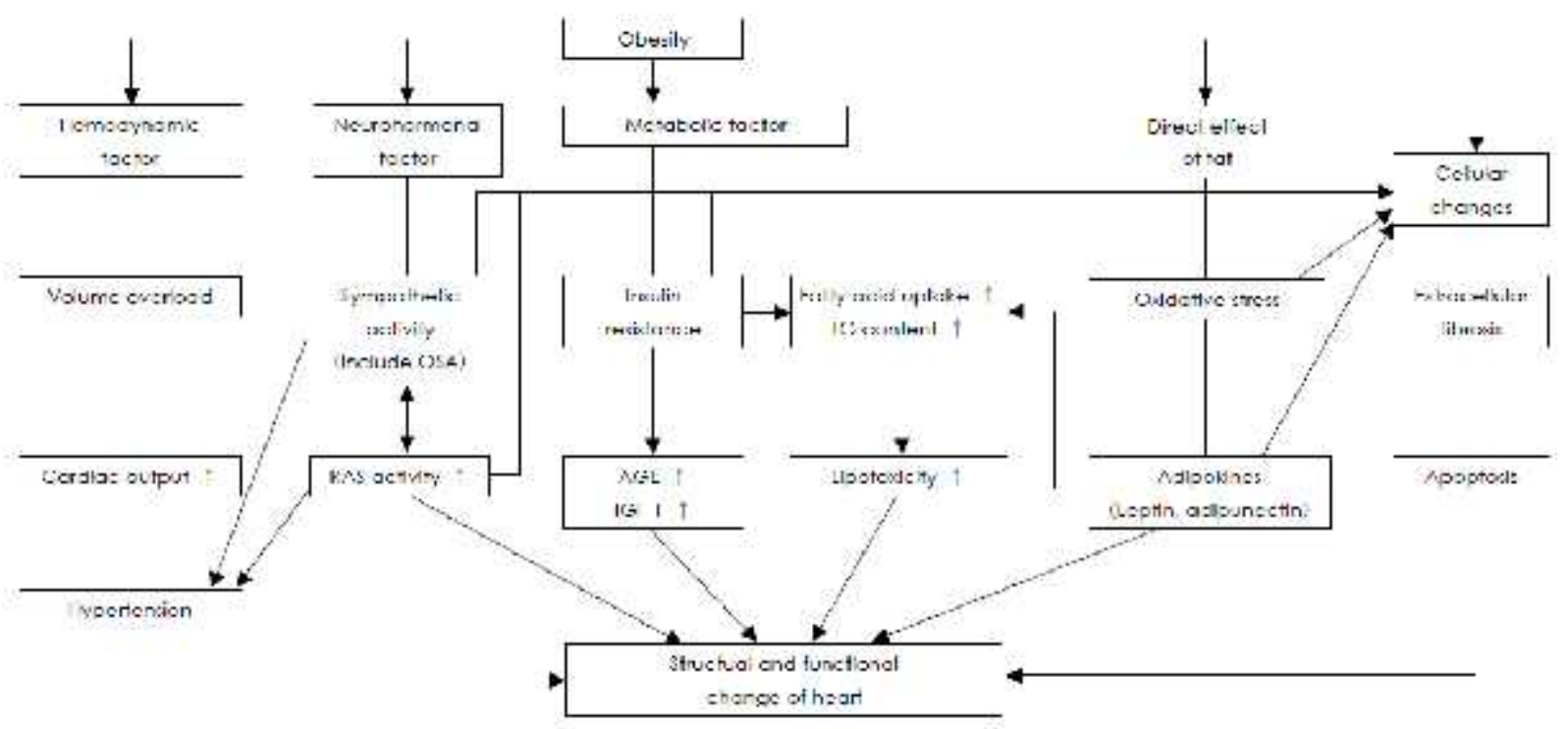

Gambar 2. Mekanisme perubahan struktur dan fungsi jantung pada obesitas ${ }^{10}$

\section{Peningkatan tekanan darah}

Mekanisme terjadinya hipertensi pada obesitas berhubungan dengan resistensi insulin, retensi natrium, peningkatan aktivitas sistem saraf simpatetik, aktivasi sistem renin-angiotensinaldosteron dan perubahan fungsi vaskular. Peningkatan aktivitas sistem saraf simpatetik pada obesitas terutama terjadi pada aktivitas simpatetik pada ginjal dan otot skeletal. Peningkatan aktivasi sistem saraf simpatetik yang berlebihan pada obesitas dipengaruhi oleh hiperinsulinemia (resistensi insulin), peningkatan leptin, adiponectin atau adipokin lainnya dan aktivitas berlebih dari sistem renin-angiotensin. ${ }^{11}$

Sebuah penelitian yang dilakukan pada anak usia 7 sampai 18 tahun menunjukkan bahwa tekanan darah berhubungan dengan ukuran tubuh. Hal ini menunjukkan bahwa obesitas merupakan faktor penting yang mempengaruhi tekanan darah pada anak. ${ }^{3}$

\section{Disfungsi endotel}

Obesitas pada anak menyebabkan disfungsi endotel. Berdasarkan hasil penelitian menunjukkan adanya hubungan yang signifikan antara lemak tubuh dan dislipidemia, resistensi insulin dan inflamasi yang menyebabkan disfungsi endotel. ${ }^{6}$

Disfungsi endotel merupakan proses awal dari perkembangan aterosklerosis. Hal ini diyakini karena adanya penurunan bioavailabilitas oksida nitrat (Nitric Oxide/NO) yang merupakan vasodilator dan juga menghambat monosit adhesi, agregasi trombosit dan proliferasi otot polos. Beberapa pendapat menyatakan adanya keterlibatan gangguan pelepasan NO yang diperantarai oleh insulin. Hal ini juga dapat menyebabkan penekanan lipolisis adiposit dan peningkatan asam lemak bebas. Disfungsi endotel berhubungan dengan hasil sekresi adiposit. Adiposit dapat mensekresi berbagai hormon peptida dan sitokin yang dapat merubah fungsi vaskular. $^{3}$ 
Ketidakseimbangan energi yang berlangsung lama dari asupan kalori berlebih menyebabkan peningkatan simpanan kelebihan energi dalam bentuk adiposit intraselular sehingga terjadi hipertrofi dan hiperplasia adiposit. Hal ini menyebabkan terjadinya disfungsi sel dengan terjadinya abnormalitas adipokin, peningkatan sirkulasi asam lemak bebas dan inflamasi serta berakibat mempengaruhi otot skeletal, otot jantung dan disfungsi endotel. Terpaparnya sel $\beta$ akibat diet karbohidrat berlebih memicu resistensi insulin dan terpaparnya hepatosit akibat lemak dan karbohidrat berlebih menyebabkan steatohepatitis dan resistensi insulin. ${ }^{12}$ Seperti yang terlihat pada gambar 3 .

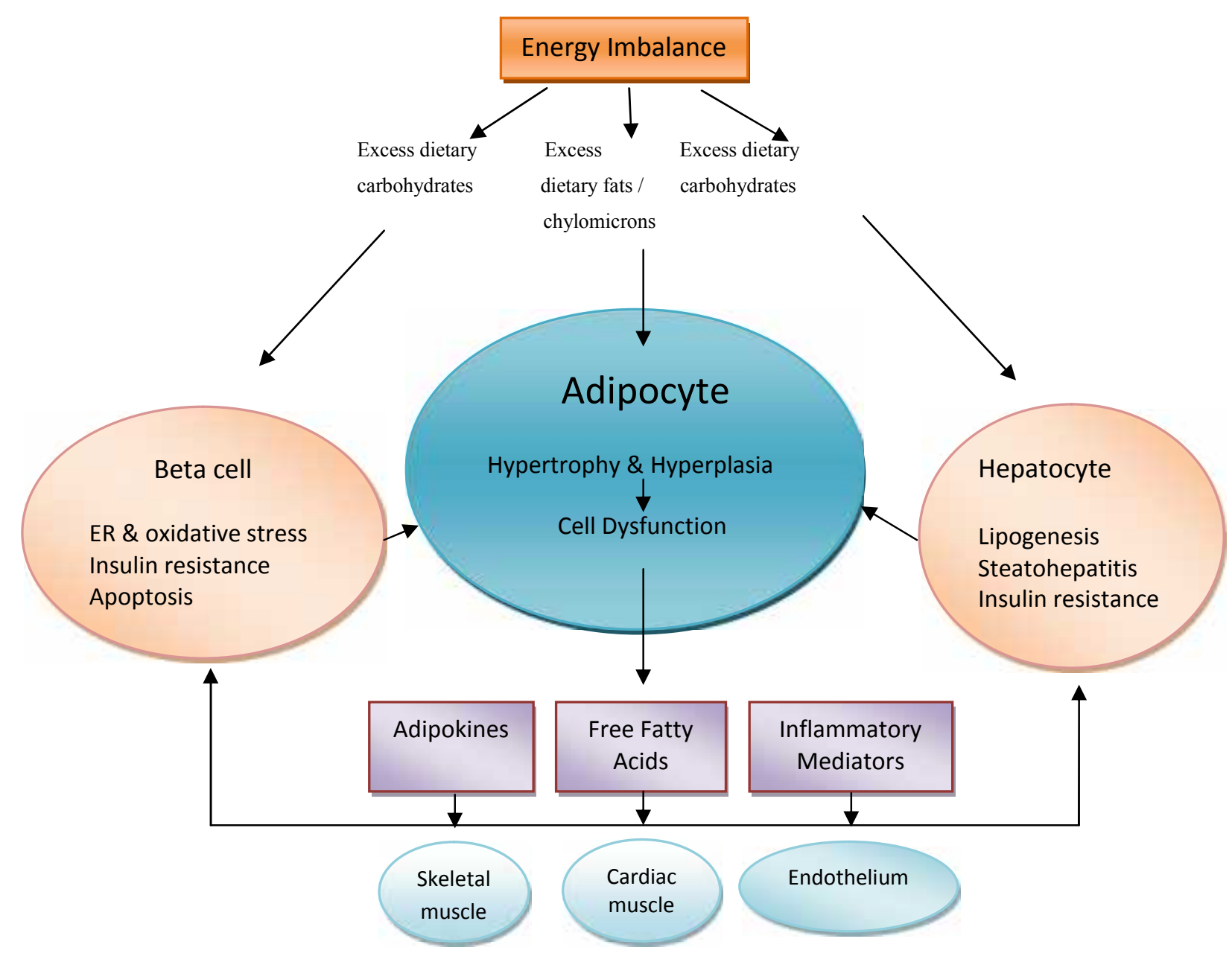

Gambar 3. Pengaruh ketidakseimbangan energi terhadap adiposit ${ }^{12}$

\section{Aterosklerosis dini}

Aterosklerosis merupakan suatu proses penyakit degeneratif pada semua manusia yang dimulai sejak masa anak namun perjalanan hingga timbul manifestasi klinis terjadi dalam rentang beberapa tahun. Manifestasi awal dari aterosklerosis berupa fatty streak yang berupa akumulasi lipid dan makrofag pada tunika intima arteri. Akumulasi lipid yang terjadi terus menerus menyebabkan proliferasi makrofag dan otot polos serta perkembangan plak fibrous. Plak akan berkembang dalam beberapa tahun dan menyebabkan nekrosis, perdarahan atau terjadi rupture 
plak. Perkembangan plak menyebabkan penyempitan lumen yang progresif dan mengakibatkan terjadinya oklusi pada pembuluh darah distal akibat embolisasi plak. (Gambar 4).

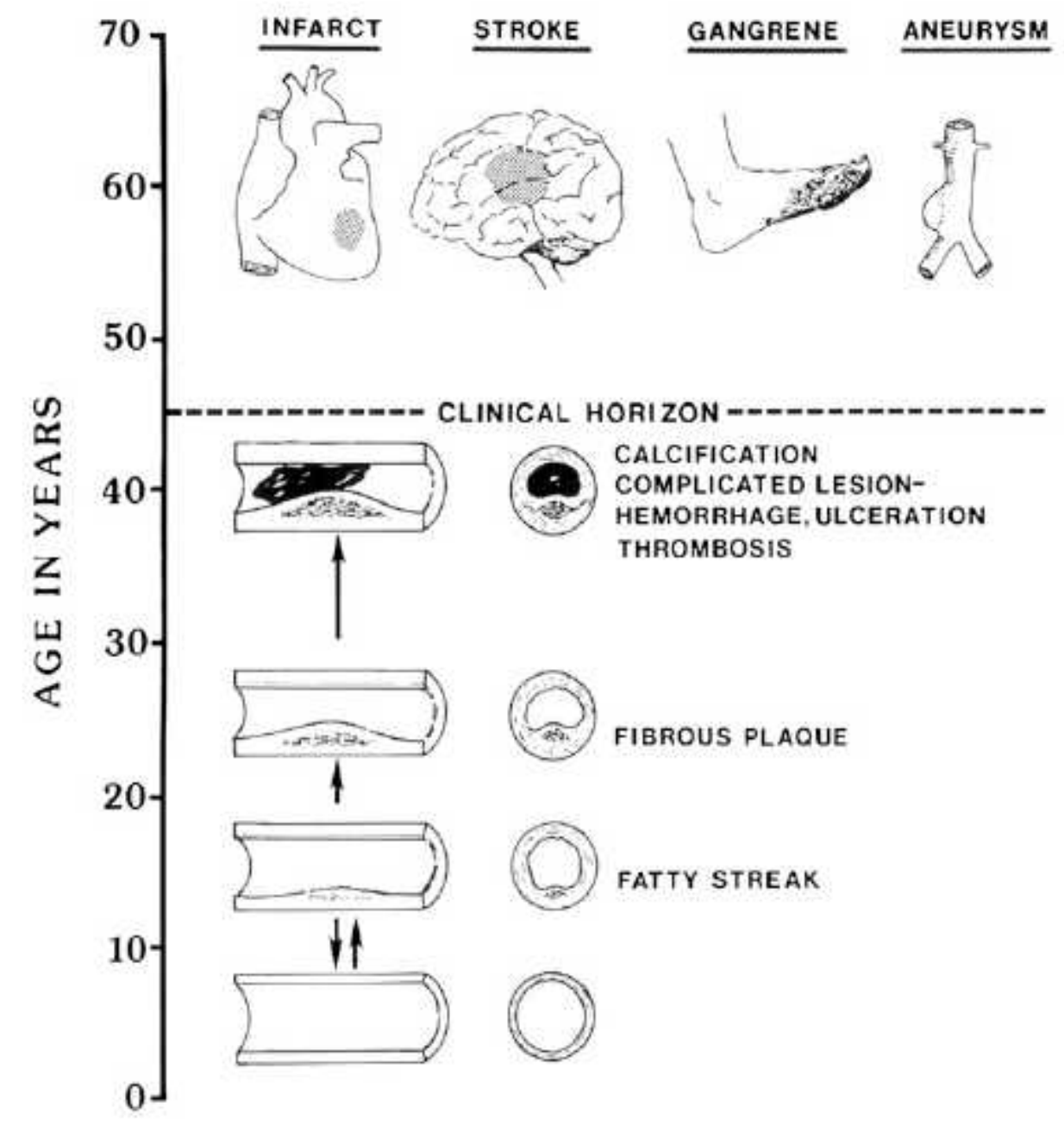

Gambar 4. Perkembangan aterosklerosis ${ }^{13}$

\section{Mekanisme disfungsi endotel dan aterosklerosis}

Suatu penelitian menunjukkan bahwa peningkatan nilai peroxy radicals (penanda stress oksidatif) pada anak obes dibandingkan dengan anak nonobes. ${ }^{11}$ Penelitian lain mendapatkan peningkatan 8-isoprostane dan hydrogen peroxide urin (penanda stress oksidatif) pada kelompok obes dibandingkan kelompok nonobes. ${ }^{14}$ Proses inflamasi dan stress oksidatif diketahui berakibat buruk terhadap kardiovaskular. ${ }^{11}$

\section{Ketebalan intima-media arteri karotis dan peningkatan kekakuan arteri karotis}

Obesitas menyebabkan peningkatan deposit lemak perivaskular di sekitar jantung dan pembuluh darah. Peningkatan jaringan lemak di sekitar pembuluh darah menyebabkan proinflamasi dan profibrotik sitokin berlebihan yang menyebabkan terjadinya inflamasi dan aterosklerosis dengan akibat peningkatan ketebalan intima media dan penurunan elastisitas arteri. ${ }^{15}$ 


\section{Dislipidemia}

Obesitas pada masa anak dan remaja memiliki konsekuensi jangka pendek dan jangka panjang akibat abnormalitas profil lemak dengan peningkatan konsentrasi kolesterol total, trigliserida dan LDL (Low-density lipoprotein) serta menurunkan konsentrasi HDL (High-density lipoprotein). ${ }^{16}$

\section{Perubahan struktur dan fungsi jantung}

Obesitas dapat memberikan efek negatif pada fungsi jantung selama usia pertumbuhan dimana dapat terjadi peningkatan massa jantung dan dimensi ruang jantung sebagai akibat dari stroke volume dan curah jantung yang besar. ${ }^{17}$

Obesitas dapat mempengaruhi otot jantung dengan beberapa mekanisme. Keberadaan obesitas sendiri dapat menyebabkan chronic volume overload dan terjadinya peningkatan curah jantung. Faktor hemodinamik dan metabolik yang berhubungan dengan obesitas dapat menyebabkan perubahan struktur dan fungsi miokardium yang dapat menyebabkan peningkatan massa ventrikel kiri. Lebih jauh lagi hipertensi yang behubungan dengan obesitas meningkatkan kerja jantung dan menstimulasi pembesaran jantung. ${ }^{18}$

Penelitian dengan menggunakan pemeriksaan ekokardiografi dan didukung dengan pemeriksaan Magnetic Resonance Imaging (MRI) jantung menunjukkan gambaran anatomi yang sama pada anak dan remaja obes dimana terlihat jantung yang lebih besar dan lebih tebal pada subyek obes dibandingkan dengan subyek nonobes. Penelitian ini juga menunjukkan pada obesitas ringan sampai sedang terlihat 15\% sampai 20\% nilai massa jantung yang lebih besar dibandingkan dengan remaja nonobes. Dari penelitian tersebut diperoleh bahwa obesitas pada dewasa dan anak-anak memiliki karakteristik pembesaran jantung dan peningkatan ukuran jantung yang berhubungan dengan keparahan atau tingkatan obesitas. ${ }^{17}$

Sebuah penelitian membandingkan penemuan ekokardiografi pada anak dengan berat badan berlebih (overweight) dan obes dengan anak yang memiliki berat badan normal pada usia 10 sampai 18 tahun. Pada penelitian tersebut tidak ditemukan perbedaan fraksi pemendekan ventrikel kiri atau fraksi ejeksi pada kedua kelompok dan tidak dijumpai peningkatan tekanan pengisian ventrikel kiri pada anak obes, namun dengan gambaran Doppler dijumpai abnomalitas fungsi diastolik pada kelompok anak dengan berat badan berlebih, hal ini mengindikasikan adanya gangguan relaksasi miokardium. ${ }^{17}$

Suatu penelitian melaporkan terjadinya peningkatan massa ventrikel kiri pada anak-anak dan remaja dengan berat badan berlebih. Hal ini berhubungan kuat dengan peningkatan tekanan 
darah sistolik dan massa tubuh serta mengindikasikan bahwa adanya hipertrofi ventrikel kiri merupakan respons kompensasi terhadap peningkatan kerja jantung. ${ }^{3}$

Penelitian yang dilakukan oleh The Bogulosa Heart Study menunjukkan hubungan yang kuat antara massa ventrikel kiri dan derajat obesitas pada anak. Pada penelitian ini dijumpai peningkatan massa ventrikel kiri pada kelompok overweight dan obes, disamping itu juga dijumpai peningkatan signifikan stroke volume pada remaja obes yang mengindikasikan peningkatan beban kerja jantung. ${ }^{2}$

Pada obesitas, perubahan pada ventrikel kiri dapat mempengaruhi fungsi ventrikel kanan. Peningkatan tekanan pengisian ventrikel kiri dapat mempengaruhi peningkatan tekanan ventrikel kanan dan menyebabkan abnormalitas ventrikel kanan tetapi dengan kemungkinan yang minimal. Hipertensi pulmonal memiliki efek penting dari fungsi ventrikel kanan tetapi peningkatan tekanan arteri pulmonalis jarang terjadi pada anak obesitas. ${ }^{19}$

\section{REFERENSI}

1. Divisi Nutrisi dan Penyakit Metabolik FK Universitas Airlangga. Obesitas pada anak. Diunduh dari: http://www.pediatrik.com/buletin.

2. Katier NV, Rooman RP, Haas L, Verhulst SL, Desager Kn, Ramet J, dkk. Early cardiac abnormalities in obese children: important of obesity per se versus associated cardiovascular risk factors. Pediatr Res. 2008; 64:205-9.

3. Ho TF. Cardiovascular risk associated with obesity in children and adolescents. Ann Cad Med Singapore. 2009; 38:48-56.

4. Jonge L, Gevers LV, Willemsen SP, Steegers EA, Hofman A, Helbing WA, dkk. Growth, obesity, and cardiac structures in early childhood. Hypertension. 2011; 57:934-40.

5. Schuster I, Karpoff L, Martin AP, Oudot C, Startun A, Rubini M, dkk. Cardiac function during exercise in obese prepubertal boys: effect of degree of obesity. Obesity. 2009; $17: 1878-83$.

6. Bhattacharjee R, Alotaibi WH, Gozal LK, Capdevila OS, Gozal D. Endothelial dysfunction in obese non-hypertensive children without evidence of sleep disordered breathing. BMC Pediatrics. 2010; 108:1-8.

7. Sjarif DR. Obesitas anak dan remaja. Dalam: Sjarif DR, Lestari ED, Mexitalia M, Nasar SS, penyunting. Buku ajar nutrisi pediatrik dan penyakit metabolik. Edisi pertama. Jakarta: Ikatan Dokter Anak Indonesia, 2011. h.230-44.

8. Archenti A, Pasqualinotto L. Childhood obesity: the epidemic of the third millennium. Acta Biomed. 2008; 79:151-5.

9. Cummings DE, Schwartz MW. Genetics and pathophysiology of human obesity. Annu Rev Med. 2003; 54:453-71.

10. Sung JK, Kim JY. Obesity and preclinical changes of cardiac geometry and function. Korean Circ J. 2010; 40:55-61.

11. Raj M. Obesity and cardiovascular risk in children and adolescents. Indian J Endocrinol Metab. 2012; 16:13-8.

12. Ferranti S, Mozaffarian D. The perfect storm: obesity, adipocyte dysfunction, and metabolic consequences. Clin Chem. 2008; 54:945-55.

13. Raghuveer G. Lifetime cardiovascular risk of childhood obesity. Am J Clin Nutr. 2010; 91:1514S-9S.

14. Ostrow V, Wu S, Aguilar A, Bonner R, Suarez E, De Luca F. Association between oxidative stress and masked hypertension in a multi-ethnic population of obese children and adolescents. J Pediatr. 2011; 158:628-33.

15. Barbosa JA, Rodrigues AB, Mota CC, Barbosa MM, Silva AC. Cardiovascular dysfunction in obesity and new diagnostic imaging techniques: the role of noninvasive image methods. Vasc Health Risk Manag. 2011; 7:287-95. 
16. Gisele M, Pegoraro M, Sandrini F, Macuco EC. Risk factors for the development of atherosclerosis in childhood and adolescence. Arq Bras Cardiol. 2008; 90:276-83.

17. Rowland TW. Effect of obesity on cardiac function in children and adolescents: a review. J Sports Sci Med. 2007; 6:319-25.

18. Li X, Li S, Ulusoy E, Chen W, Srinivasan SR, Berenson GS. Childhood adiposity as a predictor of cardiac mass in adulthood the Bogalusa Heart Study. Circulation. 2004; 110:3488-92.

19. Zeybek C, Zeybek CA, Onal H, Altay S, Erdem A, Celebi A. Right ventricular subclinical diastolic dysfunction in obese children: the effect of weight reduction with a lowcarbohydrate diet. Pediatr Cardiol. 2009; 30:946-53. 